\title{
Promoting Information Literacy of Pre-Medical Students through Project-Based Learning: A Pilot Study
}

Reya Saliba ${ }^{1 *}$, Paul Mussleman ${ }^{1}$, Melanie Fernandes ${ }^{2}$, Rachid Bendriss ${ }^{2}$

${ }^{\prime}$ Distributed eLibrary, Weill Cornell Medicine-Qatar, Doha, Qatar,

${ }^{2}$ Pre-Medical Education, Weill Cornell Medicine-Qatar, Doha, Qatar

Corresponding author: Reya Saliba, E-mail: res2024@qatar-med.cornell.edu

\section{ARTICLE INFO}

Article history

Received: May 08, 2017

Accepted: September 27, 2017

Published: October 31, 2017

Volume: 5 Issue: 4

Conflicts of interest: None

Funding: None

\begin{abstract}
This study describes the implementation of information literacy (IL) skills through the use of the project-based learning (PjBL) method in an English for Academic Purposes (EAP) course. Participants were Arabic speaking students enrolled in the Foundation Program that prepared them for the pre-medical curriculum in a U.S. medical college in the State of Qatar. A mixed methods approach consisting of a survey, three focus groups, and instructors' observations was used to gather the needed data. The results showed a significant increase in students' advanced research skills. This study emphasizes the benefit of using the PjBL method to develop students' IL skills. It also reinforces the vital role of faculty-librarian partnership in designing learning activities that engage students, foster their critical thinking, and develop their metacognitive skills.
\end{abstract}

Key words: Project-Based Learning, Problem-Based Learning, Information Literacy, English For Academic Purposes, Blended Learning, Self-Regulated Learning

\section{INTRODUCTION}

Although a working knowledge of biomedicine is imperative for non-English speaking future physicians, acquiring other essential skills is also needed, such as improving their English language, adopting the habits of lifelong learning and professionalism. In the American curriculum of pre-medical and medical education, problem-based learning (PBL) and its variant project-based learning (PjBL) foster the acquisition of these skills, teaching students how to regulate themselves, sustain motivation, and seek solutions to problems on their own while developing their English language skills and becoming effective communicators with both patients and other healthcare workers. Through the very nature of PBL assignments, physicians in training can learn to embody these abilities. In this paper, the authors aim at investigating the use of PBL and PjBL in an English for Academic Purposes (EAP) course using Information Literacy (IL) skills to develop students' critical thinking skills and self-regulated learning while improving their English language skills.

\section{LITERATURE REVIEW}

\section{Problem-Based Learning, Project-Based Learning, and Information Literacy}

Developed by McMaster University in 1969, PBL has been adopted by many medical schools as an active-learning technique that develops students' critical thinking and problem solving, both considered higher-level cognitive abilities (Wenger, 2014). Lee and Kwan (1997) describe PBL as a "you-learn-what-you-need" process where students take "ownership over their own learning," also referred to as "self-directed learning" (Wenger, 2014, p. 143). Derrick et al. (2011) report that the introduction of PBL into an undergraduate pre-medical course at Wofford College in South Carolina, USA, was, to their knowledge, the first time PBL had been used in courses at that level.

Project-based learning (PjBL) is often used to promote self-regulated learning, which requires metacognition. According to the Buck Institute of Education, PjBL is a teaching method designed to engage students in investigating complex questions while developing their knowledge and skills (Markham, Larmer and Ravitz, 2003). How it manifests in students' learning habits, especially in how students take stock in what they know, how they find information they do not know, and how they plan and implement this process of seeking out this missing information is all part of self-regulation (Zimmerman, 1990). All this, of course, depends on the degree to which the instructor allows for self-guided exploration based on the type of assignments given - whether they provide learners a chance to explore topics on their own with minimal scaffolding or whether the instructor is more involved in each aspect. Antic and Spasic (2012) describe using the PjBL approach for an English for Medical Purposes course as an essential tool that fosters students' problem-solving and critical thinking skills. 
Some studies differentiate between the educational objectives of PjBL and those of PBL. Helle et al. (2006) consider both PjBL and PBL work to start with a problem for which students will develop a plan to manage the problem, if not a solution; however, the main outcome of $\mathrm{PjBL}$ is having the students create a product whereas PBL "does not necessarily 'culminate in an end-product'" (p. 295). $\mathrm{PjBL}$ "stresses both the process and the product in the form of a project report" (Kolmos, 1996, p. 142) where students use self-regulation and work as a team to find an answer to a complex question and produce a product. In contrast, Kolmos (1996) asserts that PBL is more focused on the learning process rather than documenting the process. In fact, in PBL, the outcome does not focus on reaching a solution but rather focuses on the problem-management (Graaff \& Kolmos, 2006). Larmer (2014) concludes that both PjBL and PBL are "two sides of the same coin" and either one can be used to provide a rich learning experience for students.

The Association of College and Research Libraries (ACRL) defines IL as a "set of integrated abilities encompassing the reflective discovery of information, the understanding of how information is produced and valued, and the use of information in creating new knowledge and participating ethically in communities of learning" (ACRL, 2016). Over the past 15 years, librarians have experimented with different approaches in teaching Information Literacy (IL) skills to undergraduate students. Many academic libraries advocate the implementation of a for-credit library course for IL instruction. However, most of the IL teaching is still done through one-and-off instruction sessions where librarians are invited by faculty to sum up all IL skills in 50 to 75 minutes. Because of this constraint, no IL topics can be covered in real depth and many topics have to be left out of the instruction.

Since PjBL helps students use critical thinking skills, it is logical to introduce $\mathrm{PjBL}$ and IL simultaneously as they both deliver to students some of the same end-products. For instance, Wenger (2014) describes the integration of IL into a PBL class as an opportunity for students to develop an understanding of the entire research process as an ongoing process. This is aligned with the ACRL's new IL framework which focuses on metaliteracy and the ability of students to become not only consumers of information but also creators and dynamic participants in collaborative spaces (ACRL, 2016, p. 2).

\section{Benefits and Challenges of PBL and PjBL}

On the benefits of PBL, Iakovos et al. (2011) found that PBL creates a community in which students communicate, collaborate, and apply problem-solving skills. Students working in groups develop confidence and independence (Fried-Booth, 2002). When PBL is used in an EAP classroom, "students demonstrate increased motivation and engagement, less foreign language anxiety and positive attitudes toward language learning" (Iakovos, 2011, p. 117). Moreover, PBL helps students use critical thinking skills and "take ownership of their own learning” by applying decision-making skills (Ladews- ki, Krajcik \& Harvey, 1994, p. 499). Pinheiro (2012) believes that collaborative learning increases students' results and extends "one's knowledge from a lower level to a higher level of understanding" (Kwan, 2015, p. 60).

In a study that targeted first-year writing students at Utah Valley University, interviews were used to gather the students' attitudes towards writing while enrolled in a $\mathrm{PjBL}$ course. Preston (2015) found that students experienced "writing for the first time as, 'bits and pieces', linked to something larger, 'something of value' that gave them the "opportunity to experience writing more consciously as an assemblage" (p. 44). By doing so, students bring their memories, ideas, interests and past experiences to reflect on a chosen topic and link it to people they know who might be interested in it (Preston, 2015). Therefore, both PjBL and PBL methods are found to help students realize what they know and do not know about a specific topic, and identify what they need to know emphasizing the "learn to learn" technique rather than memorization (Wenger, 2014).

Despite being unable to show with statistical significance that undergraduate students exposed to PBL or PjBL are any more or less qualified for medical school than fellow medical students, a research paper states the definite reasons for using PBL within undergraduate student populations. Derrick et al. (2011) assert that a medical PBL course would benefit the students by expanding their interest and confidence if incorporated into an undergraduate curriculum. Even at an earlier stage than college, the use of PjBL can be beneficial. Larson et al. (1994) reported that after incorporating PBL into the curriculum for high school students who were participating in an eight-week course exploring the field of medicine, faculty and students alike agreed that through PBL they could, "effectively and thoroughly discuss medical problems and learn important concepts and details relevant to medical education" (p. 422).

Even with all the aforementioned benefits, PBL and PjBL certainly have a few drawbacks, which sometimes deter educators from using it. Some of the challenges that arise could be anything from students' failure meeting deadlines and group conflicts to lack of taking the project seriously.

The quality of the work depends on the students' work ethic and approach as individuals and members of the larger group. To overcome procrastination, students tend to cooperate rather than collaborate by dividing the work among group members who then work individually on "last minute" tasks without reviewing each other's work, which may result in fragmented work (Kwan, 2015). Students may also skip essential steps of the process (Khoiriyah et al., 2015), which results in reducing the quality of the PBL and thereby failing to meet the instructor's expectations. Furthermore, Olivo (2012) and Wang (2012) found that group work does not guarantee equal participation as active students tend to work more to compensate for their less-active peers, which makes them more frustrated.

When working in groups, conflicts can arise between members due to "substantial differences in diligence, expectations, and working styles" (Olivo, 2012, p. A87). Khoiriyah et al. (2015) distinguish between "individual dysfunctional" 
and "group dysfunctional" behaviours. While the first one is concerned with the students' poor teamwork skills, lack of commitment and personality type, the group dysfunctional behaviour refers to the group members' overall interaction, performance and achievement. The authors found that these behaviours have a considerable impact on the success of PBL and recommended "corrective actions that are in line with PBL philosophy” (p. 2) such as formative self-assessment used continuously during PBL to help students improve their learning experience as well as their collaboration.

The time involved in implementing $\mathrm{PjBL}$ is another challenge for EAP instructors and librarians. Examples of time-consuming challenges include planning and designing assignments for $\mathrm{PjBL}$; aligning $\mathrm{PjBL}$ outcomes with EAP goals and objectives; reviewing and modifying students' roles to ensure they meet the predefined requirements of the course; and creating a grading system to score students' projects. These and other preparatory tasks require continuous follow-up meetings to streamline deliverables and expectations (Carbery and Hegarty, 2011; Wenger, 2014).

\section{EAP and PjBL Method: The Role of EAP Instructors and Librarians}

A departure from traditional teaching methods, PjBL puts students at the helm of their own learning. Carbery and Hegarty (2011) describe the instructor's role in PBL as a facilitator who "guide(s) and support(s) the learning process" (p. 30) to stimulate “students' cognitive learning process and problem-solving skills" (Pagander and Read, 2014, p. 5). Bokonjic et al. (2009) believe the facilitator's role is distinct from the traditional teacher's role as he/she needs to know when to, and when not to intervene. The instructor also helps students stay motivated and focused.

EAP students enter university and are often unaware of the role of the library and its services. Many courses in higher education include a training session (or several) at the library to get students acquainted with library services, resources, staff, and the facility. However, students are not always provided with opportunities for experiential learning in conducting a search, optimizing search phrases that yield the most relevant results, or discerning which resources are credible - skills that often pose a challenge to EAP students due to their various levels of English proficiency.

Academic integrity is often a new concept to EAP students because they may come from countries in which schools rarely teach about plagiarism. Therefore, it takes a significant amount of repetition to instil this idea in these particular students. Martin et al. (2012) describe how one English as a Second Language instructor at the University of Toledo had students who "struggled with plagiarism, finding credible web sites to use as academic sources, finding and reading long articles, and problems in using citation formats" (p. 359). Though this is something that instructors face across the curriculum, EAP students are even more lacking in their understanding of how important it is to summarize, paraphrase, and quote other authors and include proper citations.

Study after study on IL in higher education advocates more collaboration between faculty and librarians, but there are not many programs that marry the two. Librarians looking for robust teaching opportunities and engaging techniques to teach IL skills will find ideal teaching partners in EAP faculty who are trying to impart some of these very same skills to their students.

\section{Study Aim and Research Questions}

Through the extensive literature review, we found that there is a lack of resources documenting the transference of IL skills to research paper writing via the PjBL method. We found no resources describing the implementation of the PjBL method in an EAP course for Arabic speaking medical students. In order to address these gaps, we decided to implement IL skills into the EAP course using the PjBL method and investigate the following research questions:

- R1: Is PjBL an effective pedagogical method for transferring Information Literacy skills into a pre-medical education curriculum?

- R2: Does the integration of Information Literacy skills using the PjBL method promote lifelong learning attributes, including teamwork, time management, and self-regulated learning?

\section{EDUCATIONAL CONTEXT AND CONCEPTUAL FRAMEWORK}

\section{Weill Cornell Medicine-Qatar's Mission}

Through a partnership with Qatar Foundation, Cornell University established an overseas branch campus of its medical school in Doha, the capital of Qatar, in 2002. The first American university to offer a medical degree overseas, Weill Cornell Medicine-Qatar (WCM-Q) was set up to provide a two-year pre-medical curriculum and a four-year medical degree track which cultivates self-inquiry and professionalism through a solid science background. In the U.S., medical students typically obtain an undergraduate degree in science before applying to a four-year medical school for a total of eight years of school. They would then go on to their specialization in a residency program and then possibly a fellowship. The pre-medical education curriculum at WCM-Q is unique in comparison to traditional American medical schools in that it offers a foundation year that helps bridge the gap from high school English and the sciences to enter and successfully complete the six-year medical curriculum.

\section{English for Academic Purposes Course}

Focusing on EAP, the Foundation English course at WCM-Q is designed to equip students with the skills to read actively and critically as well as to write essays that reflect critical thinking across genres such as cause and effect, compare and contrast, argumentative, and expository, to name a few, which often require research. In addition to reading and writing, students are often tasked to present their essay topics as well as a book of their choice. Built into the curriculum are two additional components: Critical Thinking and Information Literacy. Through a close partnership between 
Foundation EAP instructors and librarians, a project incorporating problem-based learning was introduced to foster critical thinking, collaboration, time management, professionalism, inquiry learning, and IL. At WCM-Q, fostering the partnership between EAP faculty and librarians has been proven successful. In an article documenting the process of integrating IL into the EAP curriculum at WCM-Q, Bendriss et al. (2015) described how "weekly classroom time was secured as part of the ESL course as well as a percentage of the overall grade was reserved for the IL assessments to maintain student engagement" (p. 827). The Foundation students acquired the skills in IL that were useful in their EAP writing and transferable to their science courses as well as the Global Health Seminar (Bendriss et al., 2015).

\section{Conceptual Framework}

The assignment highlighted in this study included identifying a problem and creating a mock charity organization, advocacy group, or non-governmental organization to solve that problem. For this study, the authors developed a conceptual framework based on the "seven steps" process in applying PBL as described by Bokonjic et al. (2009) and which was also found to be applied to PjBL:

1. Clarifying the topic by filling in background information and defining terms or broad concepts.

2. Defining the problem and the methods that can be used to tackle it.

3. Brainstorming keywords and synonyms. Students are expected to discuss their ideas and think out loud.

4. Generating a hypothesis or statement to be investigated.

5. Generating a research question, also known as a learning objective, which needs to be answered. Research questions should be "focused, achievable, comprehensive, and appropriate" (Bokonjic et al., 2009, n.p.).

6. Using adequate resources to locate and access relevant information on the topic. Students also apply evaluation criteria to check resources' credibility and to answer their research questions.

7. Synthesizing the acquired information, sharing and communicating findings by writing an essay and delivering a presentation.

Using and assessing the outcomes of PjBL in an EAP course can be divided into three parts. Part I is where IL is naturally incorporated as it requires students to check their background knowledge and "identify the gaps in their knowledge base" (Carbery and Hegarty, 2011, p. 30); define the new information they need to acquire; locate and access that information; evaluate the information found; incorporate this information into their knowledge base; and determine what additional information they still need and then locate and access it. "This process may repeat many times throughout the overall PBL project" (Wenger, 2014, p. 146).

Part II is concerned with students' English language skills and ability to read, understand, synthesize, and write in a foreign language. Criteria considered in this part might include "clarity of the structure, development of the subject matter, cohesion and coherence, the usage of subject specific vocabulary, [and] the formality of style" (Kucherenko et al., 2014, p. 674).
Part III involves the communication of the information found and can be assessed by both the IL and EAP instructors as it entails the choice of the communication medium, the efficient use of citations and referencing, the choice of the information to be presented and shared, and students' oral communication skills.

A Research Guide (see Appendix A) was designed to document the first six steps while students had to write an essay and deliver a class presentation as a means to evaluate step seven in which students demonstrate their ability to collect, synthesize, communicate and share their findings.

\section{DESCRIPTION OF THE PJBL PROJECT COMPONENTS}

\section{The Learning Management System as an Online Platform}

In order to increase students' engagement and develop their lifelong learning experience, the EAP faculty decided to adopt the college's learning management system (LMS) to provide an online platform from which students can access all the digital tools and resources used for this course. Through the use of LMS, instructors were able to combine class sessions with online content for a "technology-enhanced blended learning" experience (Grgurović, 2011). Online modules were created and content was built to cover the outcomes of the IL objectives and PjBL project. Assignments and quizzes were uploaded and submitted through the LMS, and students had direct access to teaching materials such as readings, audio-visual tutorials, and links to external educational resources.

\section{Description of the PBL Assignment}

On the first day of class, the assignment sheet (see Appendix $B$ ) was distributed to the 18 students enrolled in the Foundation EAP course. The information on the sheet included (a) an overview of the assignment (to create a charity organization or an advocacy group that offers medical services, supplies, or education to a target community); (b) a rationale explaining the benefits of $\mathrm{PjBL}$; (c) the three major components of the assignment (a research guide, a write-up, and group presentations) which entailed:

- a mission statement and proposed budget;

- presentation of the problem in a way that would convince the reader/audience how relevant and grave the problem is;

- finding a feasible solution to the problem, which is cost-effective and not too time-consuming;

- $\quad$ addressing likely objections to the proposed solution;

- $\quad$ submitting an annotated bibliography consisting of a minimum of three scholarly sources;

- $\quad$ a reference page in APA style.

By the end of the project, students were to hand in the following, which were used in determining each individual's grade:

1. Research Guide (including the problem, research techniques, annotated bibliography and brief outline of the write-up) (see Appendix A). 
2. Write-up (includes Mission Statement, Budget, References).

3. Group Presentations.

During the process, the EAP instructors decided to assign individual grades on the write-up as work ethics among the students varied slightly. Individual grades were also given on the presentations due to slight variations on the quality of delivery and preparation demonstrated.

\section{Description of IL Modules and Class Sessions for the Fall Semester}

During the Fall semester, librarians provided IL instruction through eight online modules and eight class sessions that took place every other week. The modules were available online one week prior to each class session and consisted of reading material, online presentations, video tutorials, and links to external sources and websites. Every module included a practice quiz and/or a graded assignment that students needed to complete and submit before class.

IL quizzes and assignments formed $10 \%$ of the total grade of the EAP course. Hands-on activities were designed for class sessions to revisit the learning outcomes and reinforce the skills covered in the online modules. Librarians facilitated discussions to help students reach the expected outcomes of the sessions and reflect on their learning.

\section{Description of IL Modules and Class Sessions for the Spring Semester}

For the Spring semester, the EAP course faculty elected to introduce a semester-long PjBL. For this project, students were split into six groups of three. Each group was tasked with creating a charity organization or an advocacy group that offers medical services, supplies, or education for a select community. Students had the entire semester to build their projects. In order to facilitate the IL portions of the students' projects, librarians, with faculty input, developed a Research Guide (see Appendix A) where students recorded their work and findings.

The Research Guide was created to divide the research process into small pieces to help students visualize and understand the research process. The Research Guide served as a log to monitor and gauge students' progress throughout the PjBL and document their work. The Research Guide was organized into four sections:

- Section I: Problem

- Section II: Research

- Section III: Annotated Bibliography

- Section IV: Write-up

Students submitted two drafts of their guides over the course of the Spring semester. Librarians reviewed the drafts and provided feedback to each group during class sessions. Each group received a grade for their final draft of the guide with librarians grading the first three sections and EAP instructors grading Section IV.

In early PjBL class sessions that Spring, librarians explained to students how to use the Research Guide, allotted class time for students to work on the first two sections of the guide, and provided assistance and direction. Librarians were also available to help students outside of class.

Throughout the semester students were required to submit their guide drafts periodically to the librarians who critiqued them using predetermined guidelines for feedback to improve students' final product. The draft contained recurring strengths and deficiencies. For instance, most groups needed to do little work to define their audience more clearly or rework their general topic statements. However, all groups needed improvement in formatting citations in APA style, developing focused and relevant background questions, and creating the best possible searches.

In the latter PjBL sessions, librarians gave feedback about the guides to individual groups, and in these same sessions, time was allotted at the end of the class for the groups to begin to improve their work while having the librarians present for feedback and input.

Librarians were very pleased to discover that, throughout the course of the semester, the work with the students to revise and refine the content of their guides continuously led to noticeable improvement in all aspects of the student projects.

\section{METHODS}

A mixed methods approach was used for this study. It has been used in social science to help collect different forms of data. Creswell (2014) believed that a mixed methods approach "provides a more complete understanding of a research problem" (p. 19) and "incorporates elements of both qualitative and quantitative approaches" (p. 3). A survey, three focus groups, and instructors' observations were used as tools to collect the needed data for this study.

\section{Study Participants}

Data were collected during the academic year - Fall and Spring semesters - of 2015-2016. The sample for the study was 18 Arab students enrolled in the Foundation Program that prepares them for the pre-medical curriculum of the six-year medical program at WCM-Q, a U.S. institution of higher education, in the State of Qatar. The Foundation Program enrols students who are graduates of secondary education in Qatar representing international, public, semi-public, and private high schools. Students are placed in the Foundation Program if they do not meet the admissions criteria to the six-year medical program. It also aims to help students develop the critical thinking skills and study habits necessary for success in the six-year medical program. Given the small class size, students attend classes, receive one-on-one help to address their areas of improvement, and meet regularly with their faculty advisors and academic counsellors to monitor their progress. Students were enrolled in the following courses: biology, chemistry, physics, mathematics, EAP, and global and public health seminar. The study participants all spoke Arabic as their first language. The average age of participants 
was 18 years old, with 17 students from Qatar and one from Bahrain.

\section{Survey}

A five-question survey that covered the different aspects of the project was used for this study. A link was sent to participants to access the survey. Almost all questions were close-ended with defined answers; the exception being the last two questions, which provided for both close-ended and open-ended responses. Out of 18 students who participated in the study, 17 submitted the online survey making for a response rate of $94 \%$.

\section{Focus Groups}

Focus groups were used to collect students' feedback regarding the project. The focus group sessions took place at the end of the project, and each group was asked five questions. Study participants were divided into three groups facilitated by two instructors per group, and session time varied between 20 and 30 minutes for each group. The researchers decided not to use any recording device due to cultural sensitivity. Beside the four researchers (two librarians and two instructors) being present for the focus groups, two additional librarians were recruited to help record the data arising from the focus group discussions. Seventeen out of 18 students participated in the focus groups (94\%).

\section{Instructors' Observations}

Throughout the semester both course instructors and librarians met regularly to discuss student progress on the project. Students, both individually and with their groups, periodically met with instructors to ask questions and receive feedback on their work. Generally, the students' work indicated that their comprehension of the project and the concepts they were being taught was constantly growing. At these meetings between students and instructors, not only were matters regarding project content addressed, but matters of group dynamics and personal interaction (e.g. personality clashes, varying work ethics, etc.) were also covered.

In instructor-student meetings in which students requested a private audience with the instructor, the topic of the meeting at least in part was likely to be some aspect of interpersonal relations within their group. Instructors dissuaded students from changing groups; rather, they encouraged students to harness differences instead and see how they could divide the work in a way that would play into their individual strengths. Instructors were pleased to see that all individuals remained within their groups and reported that the interpersonal coping skills they learned in this class would be important for future endeavours.

When students were given class time to work on their projects, the EAP instructors observed them taking full advantage of their time as well as soliciting feedback. Student questions frequently concerned matters of language and wording. There were few concerns regarding the budget though some students were interested in receiving feedback as to whether they had provided enough budgetary information.

\section{RESULTS AND DISCUSSION}

\section{Survey}

The survey collected students' perceptions of their research skills when they took part in a course carried out with the PjBL method and answered research question 1 (R1):

$\mathrm{R} 1$ : Is PjBL an effective pedagogical method for transferring Information Literacy skills in a pre-medical education curriculum?

The first question in the survey (SQ1) inquired whether the EAP instructor made the purpose of the PBL project clear to the students. Results came as follows: 69\% (10 students) "strongly agree", while 41\% (seven students) "agree". In fact, students were introduced to $\mathrm{PjBL}$ during the EAP class time and were given print forms with a detailed description of the objectives, activities, the main components (research, write-up, and group presentations), the group members' roles, and a timeline (see Appendix B).

For question 2 (SQ2), students were asked to rate the usefulness of IL sessions received during the Fall semester in regards to the $\mathrm{PjBL}$ project. Most of the students "strongly agree" (76\%, 13 students), and "agree" (11\%, two students) that the IL instruction they received in the Fall was beneficial for successfully completing their projects in the Spring. Only two students were "neutral". The quality of resources the students used for this project showed how students were able to put into practice the skills learned throughout the IL sessions in the Fall semester. The PjBL projects also reflected the students' ability to employ their critical skills in order to evaluate information including its credibility and relevance.

In question 3 (SQ3), students were asked to rate their research skills after finishing the course. Seven students (41\%) described themselves as "very confident" about their research skills, while six students $(35 \%)$ believed they were "confident", and four students (24\%) were "somewhat confident". In one study by Powell and Ginier (2013), the authors found that students usually feel less confident about their research skills after receiving IL sessions. However, in our case, we believe that since the students had the chance to apply these skills in the form of a semester-long project, they felt more familiar with doing research and more confident using these skills.

Question 4 (SQ4) inquired about the aspect of the project most beneficial to them. IL skills were given the highest rate with $65 \%$ responses ( 11 students), then the write-up section with $24 \%$ of the responses (four students), while just one student chose the budget and one the presentation (Figure 1). Students' final draft of the Research Guide confirmed these results.

A mix of online modules, hands-on activities, and class time were used for this project. Most of the students seem to prefer the class session (47\%, eight students). Another significant number of students chose the online modules (35\%, six students) as a useful teaching method, while only 
three students (18\%) preferred the hands-on activities. For this same question, students were also asked to explain the reason behind their answers. Five out of eight students who chose the class sessions commented as follows:

Student A: "Since students get to see the different methods of searching effectively and get the chance to ask questions right after the session or during the session."

Student B: "The in-class demonstration made it easier to understand and apply search techniques."

Student C: "As it's team based project, the classes help me communicate with my peers as well as my teachers."

Student D: "Cause the information was delivered in a way that made it very understandable."

Student E: "Because we can ask questions until it is clear enough."

Two students who chose the online modules commented:

Student F: "Because they were very clear and detailed."

Student G: "You can open the module whenever you are ready to gain knowledge, which makes the experience more beneficial."

One of the three students preferred hands-on activities:

Student H: "Because they make the minds and the bodies move."

Based on their answers, it would be ideal to further merge online teaching with in-class sessions in this course to create an even more robust blended learning environment.

\section{Focus Groups Results}

The following results from the focus groups answered research question 2:

R2: Does the integration of Information Literacy skills using the PjBL method promote lifelong learning attributes, including teamwork, time management, and self-regulated learning?

After completion of the project, researchers divided the students into three groups, and each group participated independently in a singular, concurrently conducted, focus group session. These sessions were undertaken so as to gauge the students' perception of the effectiveness of the project, the difficulties they had while working in groups, and their suggestions for improving the project for next year. Below, the authors have grouped student answers by recurring themes.

In question 1 (FQ1), students named the skills they wished they had possessed prior to the project. Although students received a detailed description of the project, most of them admitted feeling confused and wanting more direction and guidance, especially when deciding their topic (this can perhaps be explained by the fact that students had not been involved in this type of independent, experiential learning before). Some students also mentioned that they lacked the organizational skills that are described in more detail in the next question (Figure 2).

Students were asked in question 2 (FQ2) to describe the obstacles they encountered while working on their project. Organizational skills coupled with confusion were common concerns. Students described dealing with deadlines for task completion to be chief among the hurdles they faced for this project. Many students reported lack of commitment from other group members and poor time management. Some students raised concerns regarding communication with in-

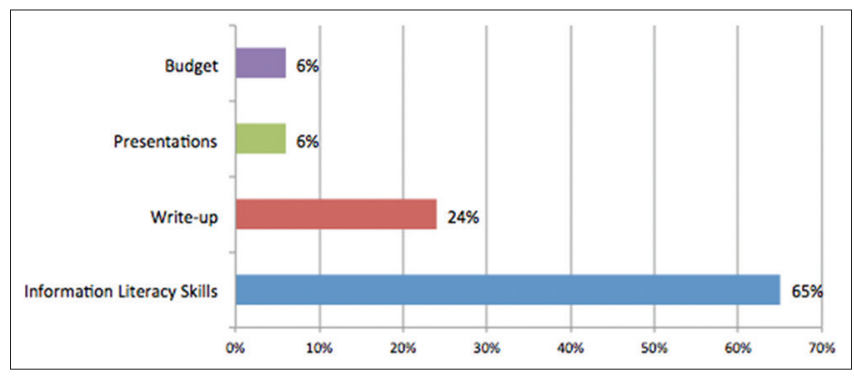

Figure 1. Participants' answers to SQ4

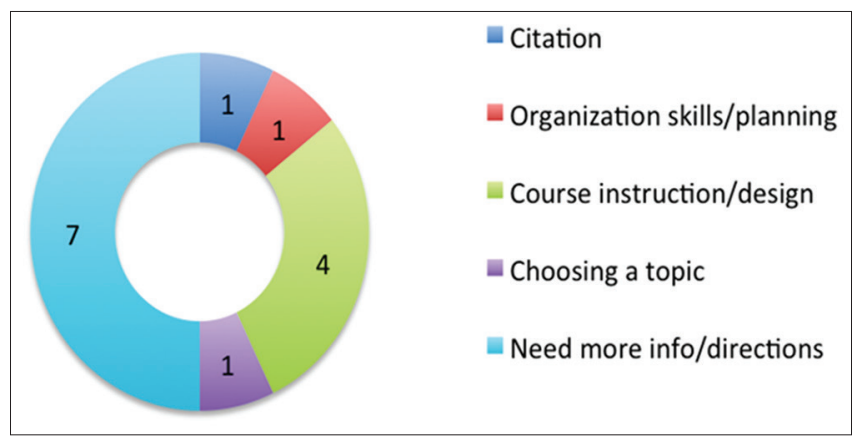

Figure 2. FQ1: Students wished they had more

information/directions prior to starting the PBL project

structors, such as receiving conflicting advice from different instructors. However, for some groups, students found that the workload was distributed evenly, the communication was smooth, and the group leader did a good job keeping everything on track and within the time frame. Ultimately, all students were able to work through the problems arising within their groups (without having to change up group members) and complete the project (Figure 3).

In question 3 (FQ3), students were asked to name the aspects they particularly liked about the project. Most of the students believed that the project helped them develop their interpersonal communication skills and shape their professional behaviours (nine students). Similarly, the equivalent number of students stated that PjBL taught them how to prioritize tasks and manage their time. Students also enjoyed "creating" a new organization and working on a budget for the organization (six students). Some students identified collaboration among group members as another aspect of PjBL that they enjoyed. A number of students reported that the Research (four students) and critical thinking components (five students) of the project were helpful, and that the IL skills they learned during the Fall semester were directly applicable to the project. This is consistent with the findings of the survey results for question SQ4 (Figure 4).

For question 4 (FQ4), when asked to enumerate any confusing or unclear points, seven students out of 17 stated again that they felt they needed more direction, and that they sometimes received inconsistent messages from the different instructors. However, these findings do not conform with the survey results to question SQ1 in which all students agree that the instructors made the purpose of the project clear. This need for more direction can likely be attributed to cultural and educational practices in the Arab world, and within the Gulf region specifically, where students expect to receive 
close guidance from the teacher instead of being exposed to an independent learning approach.

In the last question (FQ5), students were invited to share any idea(s) that they thought would improve the project for next year. Some of the students suggested that in future sessions the personality types contained in each group should be diversified in order to generate a cohesive group with all members contributing equally to reach the same goal. Students also recommended having more varied topics (i.e. not necessarily only those related to medicine). They also indicated that the feedback of the instructors was very valuable. One student suggested that it might be helpful to have a designated librarian and instructor to work with each group in order to minimize inconsistent messages and mixed feedback arising from the instructors and librarians. It was also suggested by one student that a competitive component (perhaps even including prizes) be built into their project in order to increase student investment and excitement in the project (Figure 5).

Advice from current students to future students engaging in this project includes the following:

"Have fun with the project, enjoy, believe in it, learn."

"Don't get defensive when given feedback."

"Make a schedule."

"Pick a leader."

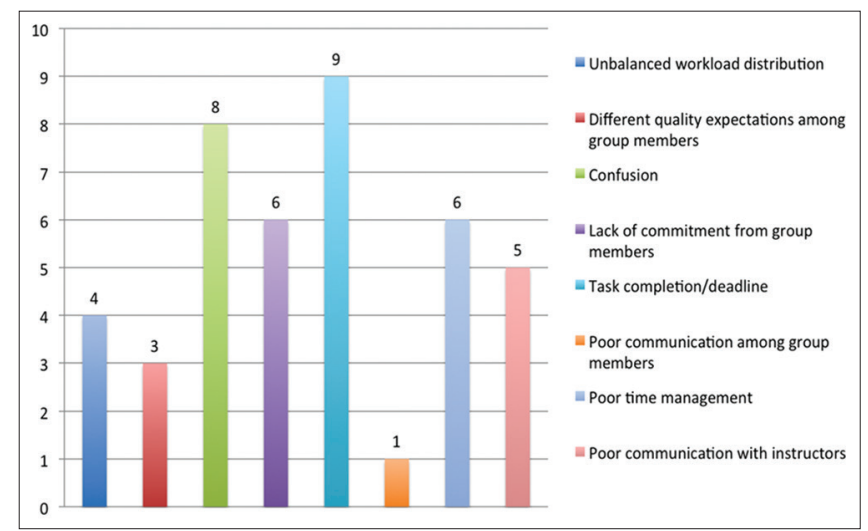

Figure 3. FQ2 describes the obstacles and frustrations students dealt with during the PBL project

\section{Instructors' Observations}

Instructors' observations summed up the three different components of the PjBL project (the Research Guide, the Write-up and the Group Presentations), which supported the findings of the survey and the focus groups. This section answered both research questions R1 and R2:

$\mathrm{R} 1$ : Is PjBL an effective pedagogical method for transferring Information Literacy skills in a pre-medical education curriculum?

R2: Does the integration of Information Literacy skills using the PjBL method promote lifelong learning attributes, including teamwork, time management, and self-regulated learning?

\section{Research guide}

In order to improve the learning process, it is essential for instructors to provide timely feedback to students while they are working on their drafts. It is also important to encourage students to generate continuous feedback about their projects, including the research process, the findings, the dynamics of the group, and other concerns as they arise.

As students were developing the research guides, librarians noticed a significant improvement in students' research skills: the use of relevant keywords, the ease of searching databases using advanced techniques, and the confidence in critically evaluating resources and deciding their credibility, relevancy, and usefulness for the topic at hand. In-class sessions were very valuable as they provided students with an atmosphere in which they did not hesitate to ask for assistance and feedback.

\section{The write-up}

A technical writing assignment, the write-up and its several components, helped students to explain a complex problem and to provide solutions that went from teaching triage skills to refugees to urging the government to create and enforce strict car seat laws for children.

When students had questions regarding what to include in the write-up, EAP instructors advised them to look at

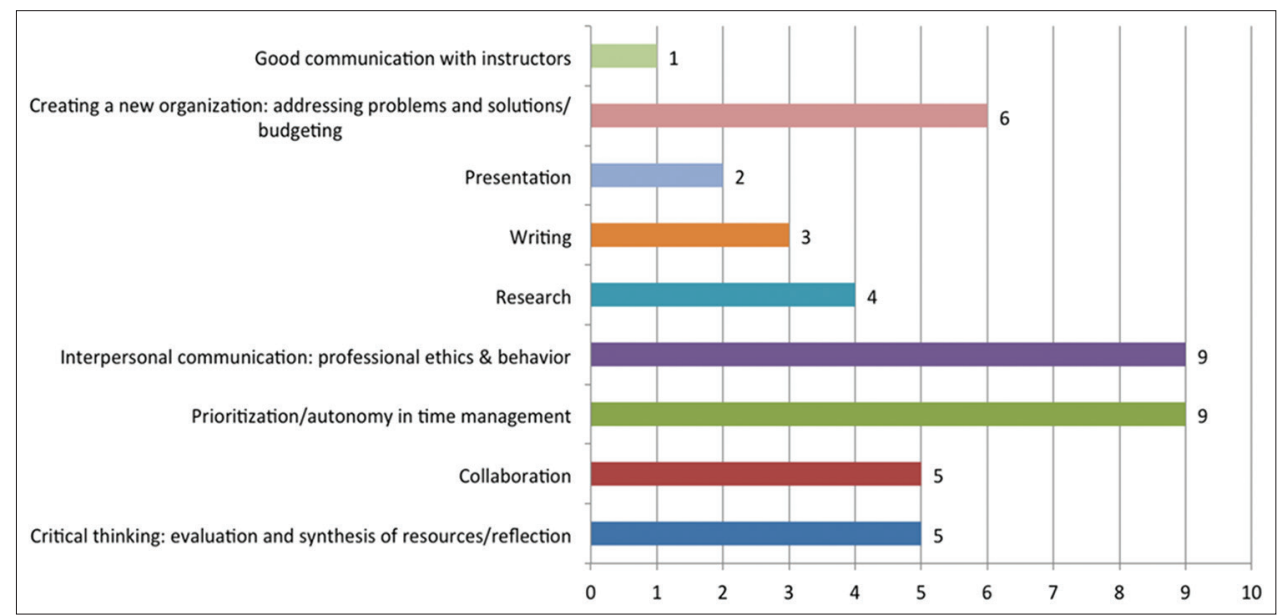

Figure 4. FQ3: Students' ranked interpersonal communication and task prioritisation as being the aspects of the PBL project most liked 


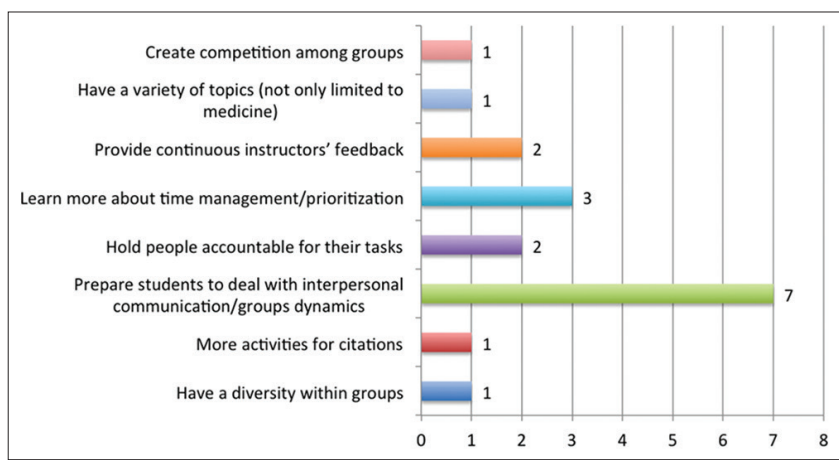

Figure 5. FQ5: Students's suggestions to improve PBL for next year

similar organizations' websites in order to get an idea of how to include enough background information on the subject without being overwhelming to the reader. In addition, they would be able to see mission statements and the kind of work these particular NGOs or advocacy groups do. Not many NGO or advocacy group websites posted their budget, so the students could not find clear examples of budgetary concerns. However, all students had the opportunity to hear a paediatrician speak during their Career Seminar classes regarding how she pieced together her organization by gathering supplies and filling the gaps for the needs of her target population. All of the student groups were detail-oriented in the way they provided treatment for their target population as well as very creative in their solutions. EAP instructors strongly encouraged students to seek help from medical professionals so that all angles would be considered and there would be no holes in the write-up or the presentation. However, very few groups took the initiative to speak with a medical professional, and they subsequently learned from audience member questions (arising after their presentations) that there were crucial bits of information that could have been included in their essays.

\section{Group presentations}

Students delivered group presentations for each of their projects. Each group prepared 15-minute oral presentations using Microsoft PowerPoint for their slideshows. The audience consisted of classmates, faculty, and staff members. Topics included (a) psychological/medical support for children who were victims of trafficking in Nepal; (b) child safety in vehicles in the State of Qatar; (c) medical/psychological support for victims of domestic violence in Bihar, India; (d) advocating enforcement of labour laws and proposing new laws for the protection of construction workers' human rights in the State of Qatar; (e) teaching triage skills to Syrian refugees in Zaatari camp, Jordan; (f) HIV/AIDS awareness campaign in the Sub-Saharan region.

During their presentations, most of the students showed self-confidence, excitement, and preparedness while delivering their talk. The slides were carefully prepared and helped guide the presentations without excessive text. Images and short video-clips were used by some groups for the purpose of thematic clues, while other groups used pictures to seek the audience's empathy to some humanitarian cause. All the presentations had information organized and arranged clearly, stating the topic, the mission statement of the charity organization or advocacy group, a budget and the expected results they plan to achieve by implementing their project. Students also used and cited a variety of resources that showed the depth of research they did for this project. Some of the topics generated lively discussions, and students were able to answer almost all of the audience's questions based on their findings and the background knowledge they gathered for this project. One of the audience members had some tough questions for the group who worked on educating the Sub-Saharan region of Africa on AIDS. By this impromptu feedback, the students took the questions or comments in stride, giving them a real-world simulation of presenting to people they are not acquainted with and thinking on their feet.

\section{RECOMMENDATIONS, LIMITATIONS, AND CONCLUSION}

This study described the implementation of IL through the PjBL method for Arabic speaking premedical students enrolled in an EAP course. In preparation for this project, librarians decided to cover the needed IL skills during the fall semester, giving students enough time to process and practice these skills. By the time the PjBL was introduced, during Spring semester, students had already acquired the necessary skills and were able to reflect on them and put them into practice. The partnership between librarians and EAP instructors had a major role in the success of this project. The results showed a significant increase in students' research skills such as using advanced search techniques when searching databases, evaluating resources and making sound judgments regarding the relevancy, accuracy, and credibility of information. Students felt more confident doing research and recognized the importance of the IL sessions they received. The results also showed that students' preferences were divided between the online modules and the in-class sessions, which emphasizes the positive impact and complementarity of using a blended learning approach for PBL. Students were also able to voice their concerns regarding this project and provided valuable feedback.

Based on these results and taking into consideration students' feedback, a successful integration of IL skills into an EAP course for Arabic speaking students requires the following:

- $\quad$ building a strong partnership between EAP instructors and librarians;

- $\quad$ having enough time to brainstorm and plan the activities for the project;

- having regular meetings prior to the project and throughout the semester to fine-tune the project and address any questions as they arise;

- $\quad$ providing the students with a "road map" that would clearly describe the objectives and outcomes of the project, and giving them a timeline to help organize their work;

- $\quad$ using the blended learning approach where students have online access to resources and materials and at the 
same time are able to meet in a class setting, practice through hands-on activities, communicate with peers, and get instant feedback from instructors;

- $\quad$ allocating and designating one EAP instructor and one librarian for each group as mentors to follow-up on their project, provide constructive feedback, and work out any miscommunication or unequal contribution from group members;

- $\quad$ prior to the project, introducing students to teamwork and time management skills to avoid conflict and encourage open communication and commitment from all group members;

- inviting the academic community including faculty members and other students to group presentations and encouraging discussions, feedback, and comments from the audience.

This study investigated the possibility of integrating IL skills using the PjBL method in an EAP course. The results gathered showed the positive impact that such integration might have on promoting lifelong learning, self-regulated learning, and developing medical students' research skills. However, there were certain limitations that the authors would like to acknowledge. First, the small sample size of the participants makes this research difficult to replicate for larger groups and generalize its findings. Second, the particular background of students participating in this study (Arabic students enrolled in a pre-medical program offered by an American institution in the State of Qatar) does not allow the findings to be generalized. Finally, students' course load might have affected the quality of their work and commitment, and thus provided biased feedback.

For this study, we combined the expertise of the librarians and EAP instructors to create an improved version of the then current ACRL's IL Standards (2000). This enabled us to design our own learning outcomes, which would foster students' metacognitive skills. In fact, the new "Framework for Information Literacy for Higher Education" that was drafted and then adopted earlier this year by ACRL, recognizes metaliteracy as "a renewed vision of information literacy" that describes students as "consumers and creators of information who can participate successfully in collaborative spaces" and become "more self-directed in that rapidly changing ecosystem" (ACRL, 2016). The authors of this study believe that this recent release by the ACRL of the new IL framework reinforces the significance of integrating IL skills into PjBL.

\section{REFERENCES}

Antic, Z, \& Spasic, D. (2012). Project-based learning in English for medicine. Acta Medica Medianae, 51(2), 5055. doi:10.5633/amm.2012.0210

Association of College \& Research Libraries (ACRL). (2000). Information Literacy Competency Standards for Higher Education. Retrieved from http:/www.ala.org/ acrl/standards/informationliteracycompetency

Association of College \& Research Libraries (ACRL). (2016). Framework for information literacy for higher education. Retrieved from http://www.ala.org/acrl/standards/ilframework
Bendriss, R., Saliba, R., \& Birch, S. (2015). Faculty and librarians' partnership: Designing a new framework to develop information fluent future doctors. The Journal of Academic Librarianship, 41(6), 821-838. doi:10.1016/j. acalib.2015.09.003

Bokonjic, D., Mimica, M., Pranjic, N., Filipovic, V., Cosovic, S., Bosse, H., Huwendiek, S., \& Kirschfink, M. (2009). Chapter 7: Problem-based learning. In Steiner, T., Sonntag, S. G., \& Bokonjic, D. (Eds.), Manual of Teaching and Learning in Medicine (n.p.). Retrieved from http://www.bhmed-emanual.org

Carbery, A., \& Hegarty, N. (2011). Introducing problem-based learning into one-shot information literacy instruction at Waterford Institute of Technology Libraries. SCONUL Focus 53, 30-33.

Creswell, J. W. (2014). Research Design: Qualitative, quantitative and mixed methods approaches ( $4^{\text {th }}$ ed.). Washington DC: Sage.

Derrick, W., Shiflet, G., \& Weaver, E. (2011). Medical problem-based learning in an undergraduate pre-medical course: A six-year study. Journal of the South Carolina Medical Association (1975), 107(6), 218-221.

Fried-Booth, D. L. (2002). Project work (2 $2^{\text {nd }}$ ed.). New York: Oxford University Press.

Graaff, E, \& Kolmos, A. (Eds.). (2006). Management of change implementation of problem-based and project-based learning in engineering. Netherlands: Sense Publishers.

Grgurović, M. (2011). Blended learning in an ESL class: A case study. CALICO Journal, 29(1), 100-117.

Helle, L., Tynjala, P., \& Olkinuora, E. (2006). Project-based learning in post-secondary education - theory, practice and rubber sling shots. Higher Education, 51, 287-314. doi: 10.1007/s10734-004-6386-5

Iakovos, T., Iosif, F., \& Areti, K. (2011). Content-based instruction in the teaching of English as a foreign language. Review of European Studies, 3(1), 115-121.

Khoiriyah, U., Roberts, C., Jorm, C., \& Van der Vleuten, C. P. (2015). Enhancing students' learning in problem based learning: Validating of a self-assessment scale for active learning and critical thinking. BMC Medical Education, 15(140). doi:10.1186/s12909-015-0422-2

Kolmos, A. (1996). Reflections on project work and problem-based learning. European Journal of Engineering Education, 21(2), 141-148.

Kwan, L. S., \& Yunus, M. M. (2015). Group participation and interaction in ESL Wiki collaborative writing among Malaysian gifted students. Asian Social Science, 11(2), 59-68. doi:10.5539/ass.v11n2p59

Ladewski, B. G., Krajcik, J. S., \& Harvey, C. L. (1994). A middle grade science teacher's emerging understanding of project-based instruction. Elementary School Journal, 94(5), 499-515.

Larmer, J. (2014). Project-based learning vs. problem-based learning $v$ s. $X-B L$. Retrieved from http://www.edutopia. org/blog/pbl-vs-pbl-vs-xbl-john-larmer

Larson, B. H., \& Gilmore, H. T. (1994). Expanding the concept of problem-based learning to prospective medical 
students. Academic Medicine: Journal of the Association of American Medical Colleges, 69(5), 421-422.

Lee, R., \& Kwan, C. (1997). The use of problem-based learning in medical education. Journal of Medical Education, 1(2), 149-157. Retrieved from http://fhs.mcmaster.ca/mdprog/documents/Use_of_PBL_Article. pdf

Markham, T., Larmer, J., \& Ravitz, J. (2003). Project based learning handbook: A guide to standards focused project based learning for middle and high school teachers. Novato, CA: Buck Institute for Education.

Martin, J. A., Reaume, K. M., Reeves, E. M., \& Wright, R. D. (2012). Relationship building with students and instructors of ESL: Bridging the gap for library instruction and services. Reference Services Review, 40(3), 352-367. doi:10.1108/00907321211254634

Olivo, R. F. (2012). Collaborative online writing assignments to foster active learning. The Journal of Undergraduate Neuroscience Education, 11(1), A82-A89.

Pagander, L., \& Read, J. (2014). Is problem-based learning (PBL) an effective teaching method? A study based on existing research. Linköpings universitet, Filosofiska fakulteten. Retrieved from http://www.diva-portal.org/ smash/get/diva2:726932/FULLTEXT01.pdf
Pinheiro, P. A. (2012). Collaborative writing by means of digital tools: Resignifying textual production in the school context. Retrieved from http://www.interesjournals.org/IRJASS/pdf/September/Pinheiro.pdf

Powell, C. A., \& Ginier, E. C. (2013). Lessons learned: Yearby-year improvement of a required information competency course. Medical Reference Services Quarterly, 32(3), 290-313. doi:10.1080/02763869.2013.806862

Preston, J. (2015). Project(ing) literacy: Writing to assemble in a postcomposition FYW classroom. College, Composition, and Communication, 67(1), 35-63.

Wang, C. M. (2012). An investigation of using wikis as a collaborative tool for teaching in a non-western tertiary education classroom. Journal of Educational Technology Development and Exchange, 5(1), 63-76. Retrieved from http://www.sicet.org/journals/jetde/jetde12/5-Wang.pdf

Wenger, K. (2014). Problem-based learning and information literacy. Pennsylvania Libraries: Research and Practice, 2(2), 142-154. doi:10.5195/palrap.2014.61

Zimmerman, B. J. (1990). Self-regulated learning and academic achievement: An overview. Educational Psychologist, 25(1), 3-17. Retrieved from http://itari.in/ categories/ability_to_learn/self_regulated_learnin_g_ and_academic_achievement_m.pdf 


\section{Appendix A: Research Guide}

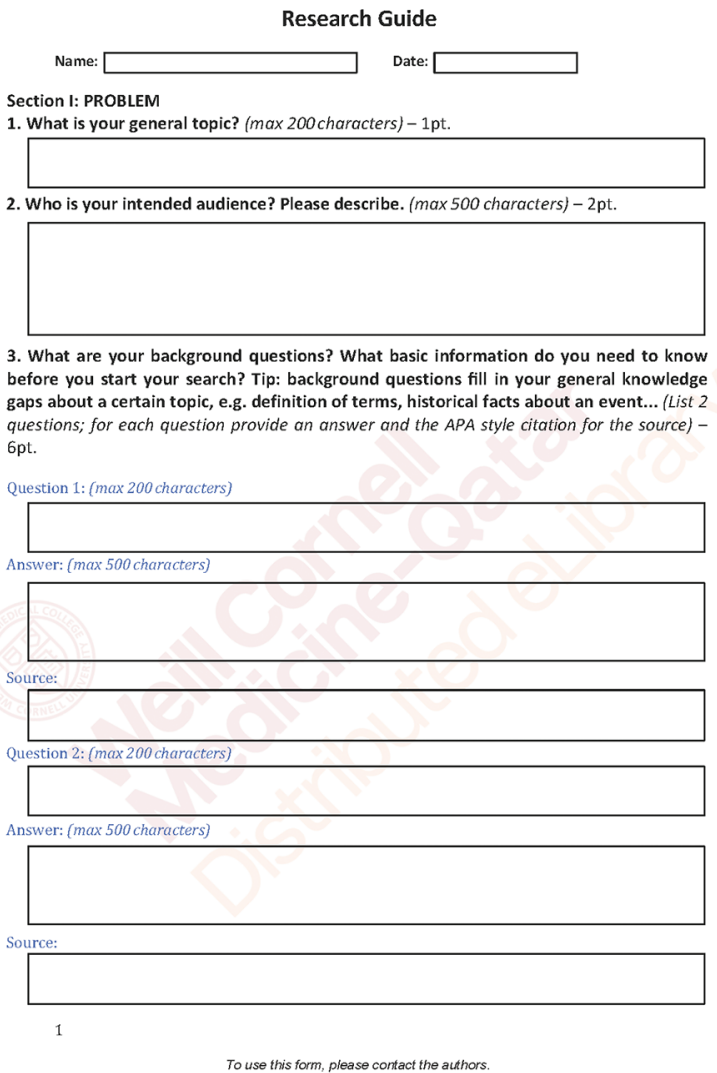

Section II: RESEARCH

7. List 4 information sources (databases, search engines...) and copy/paste the exact search string that you used (including Boolean operators, truncation and phrasing). Remember to add any filters you used and the number of results. $-8 \mathrm{pt}$.

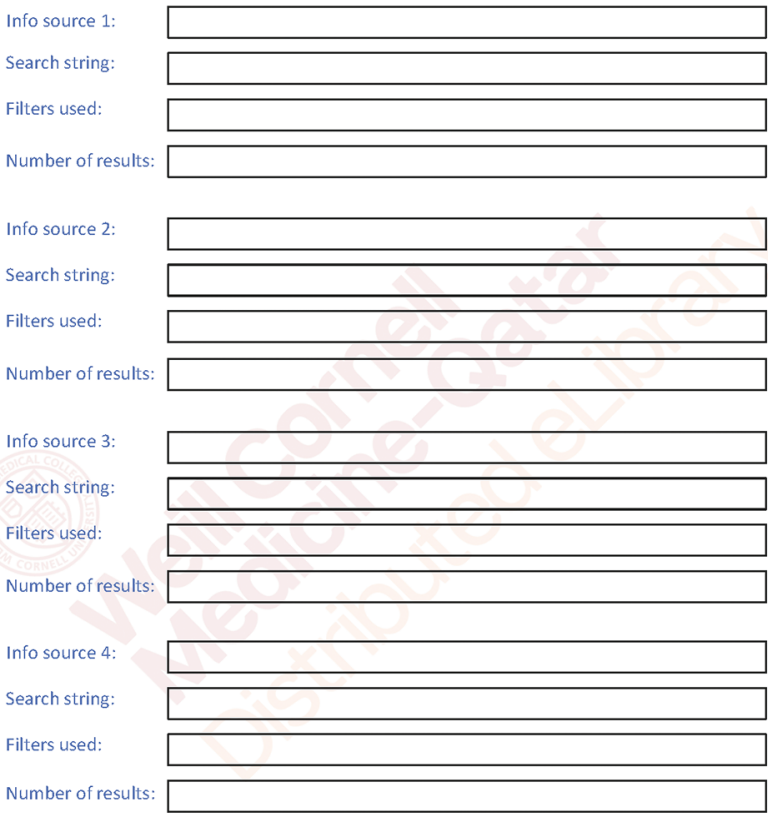

4. List 2-3 possible questions you want to answer about your topic. (max 500 characters) $3 \mathrm{pt}$

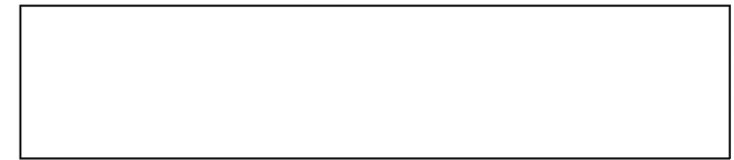

5. What keywords would you use to search for your topic? What synonyms or related terms can you use? (You can draw a mind map to easily visualize yourtopic). - 3pt.

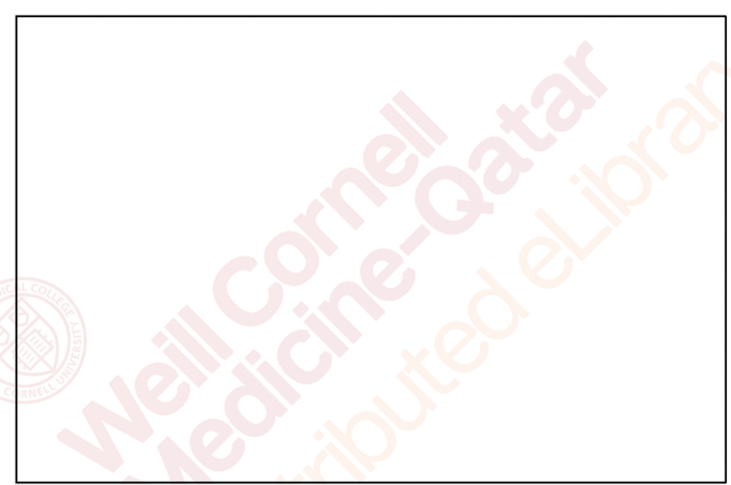

6. Clearly and concisely state your focused topic. (Your focused topic can be $a$ thesis statement or a research question - max 500 characters). $-3 p$

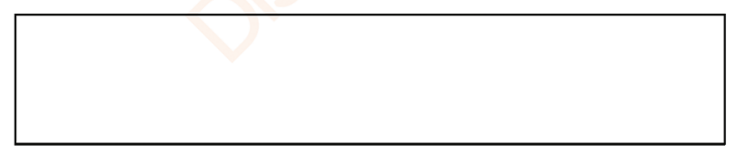

To use this form, please contact the authors.

8. Comment on your search results. How well do your results reflect your research question? Are you surprised by the number you found? What proportion of your results is relevant? Are there any odd or unusual results - if so, why? (Please include any further comments, explanations, or questions that you feel need to be included here. Be as descriptive as possible) - $8 \mathrm{pt}$

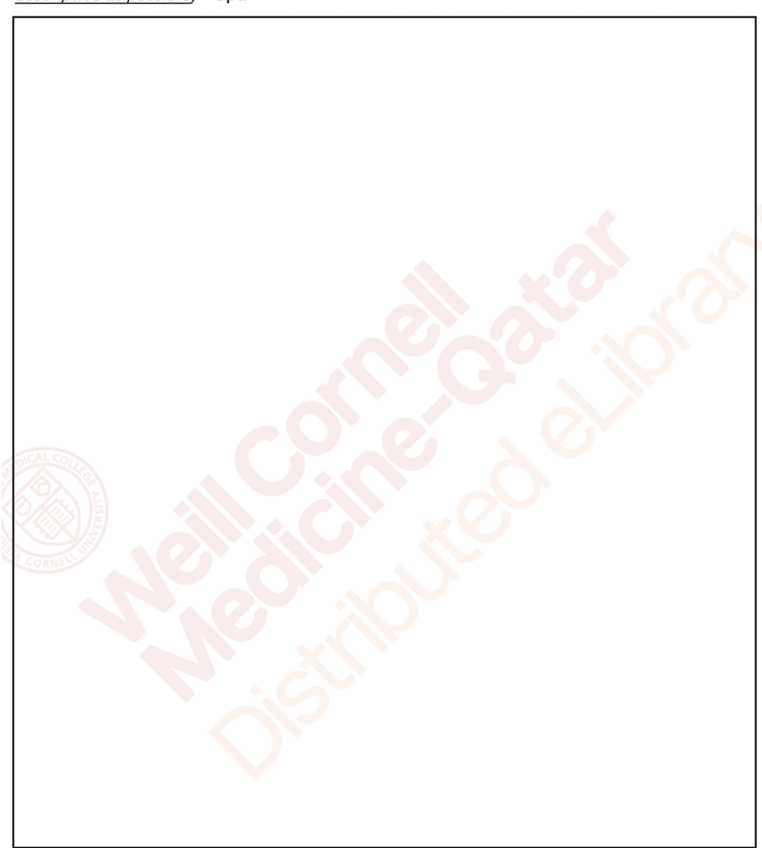


9. Do you need to change your information sources or keywords to retrieve more relevant results? If yes, list each information source you used (databases, search engines...), and copy/paste in the exact search from the search box (including Boolean operators, truncation and phrasing). Remember to add any filters you used as well the number of results.

Info source 1:

Search string:

Filters used:

Number of results:

Info source 2:

Search string:

Filters used:

Number of results:

Info source 3:

Search string:

Filters used:

Number of results:

Info source 4:

Search string:

Filters used:

Number of results:
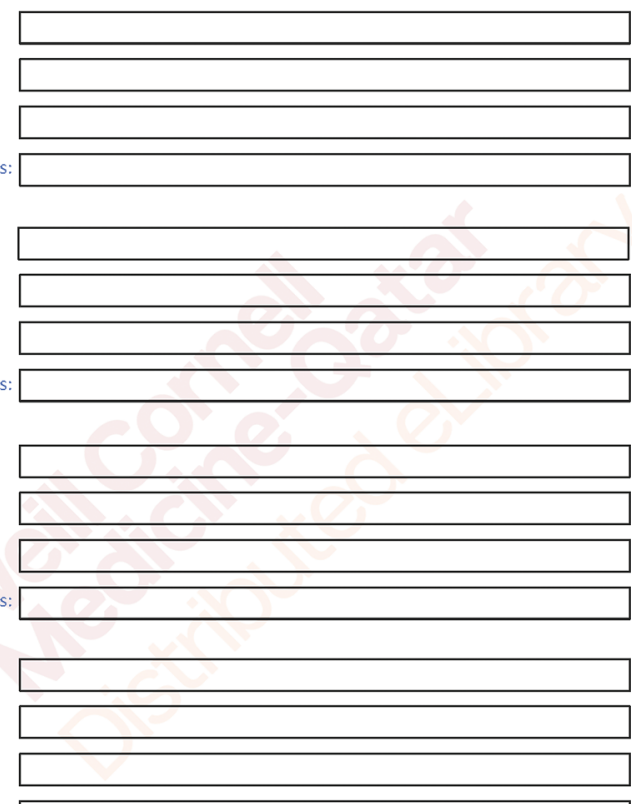

$$
\text { ults: }
$$

To use this form, please cortact the authors.

Section IV: WRITE-UP

11. Using the search results, briefly outline the different parts of youressay. $-7 \mathrm{pt}$
Section III: ANNOTATED BIBLIOGRAPHY

10. Pick the 3 most relevant sources and write an annotated bibliography for each of them using the APA style (do not forget to evaluate the sources; apply the CRAAP test for online information sources - max 1500 characters, each). - 9pt.

Source 1:

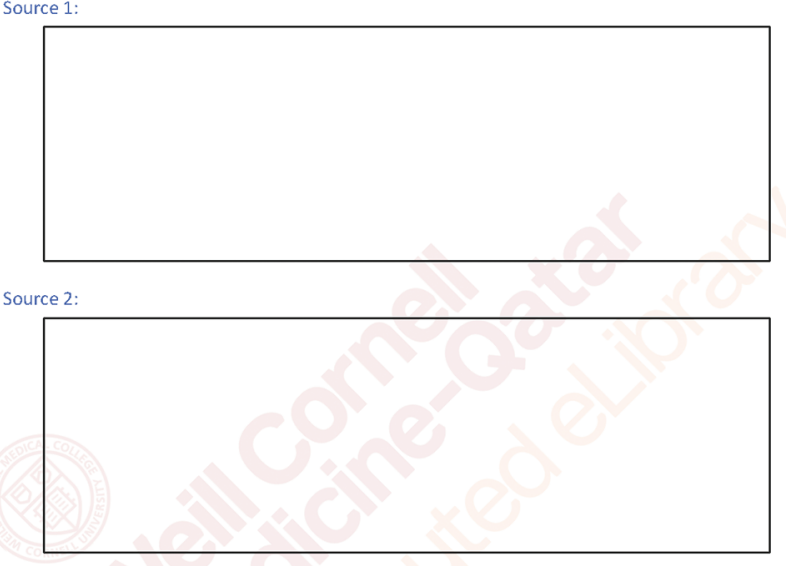

Source 3:

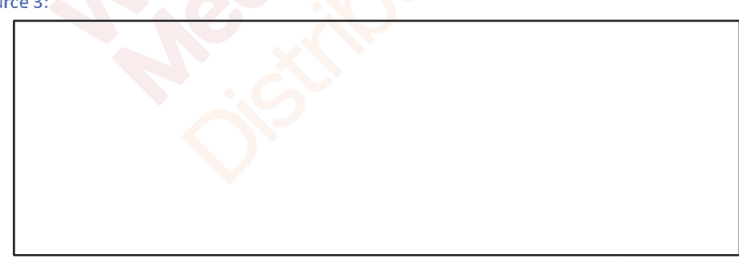

To use this form, please contact the authors

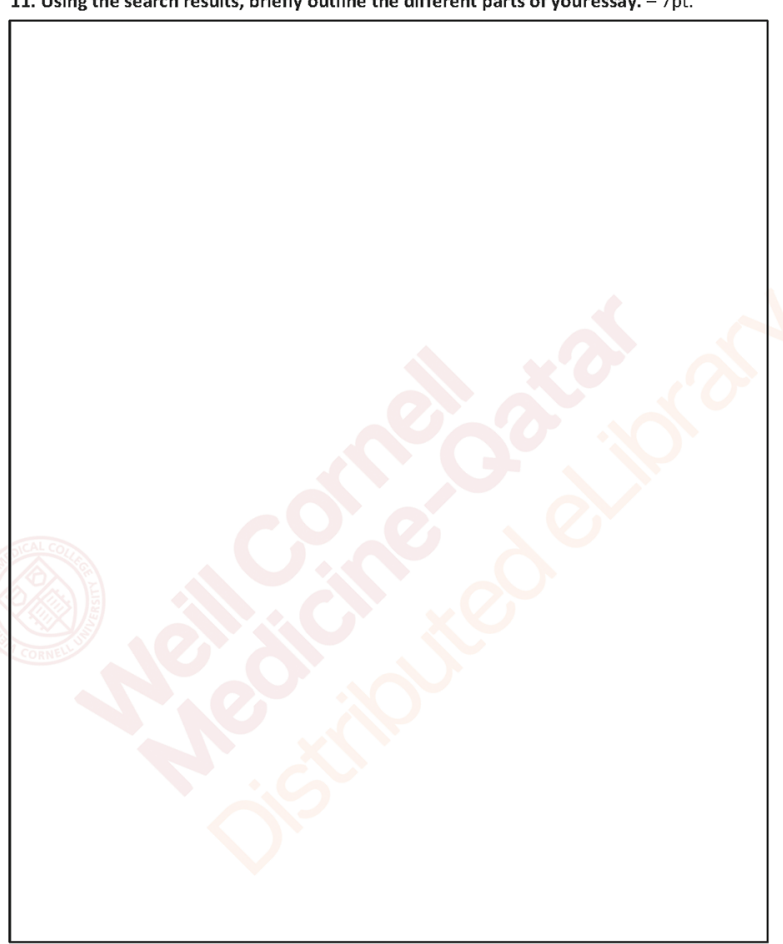




\section{Appendix B: PBL Assignment}

\section{Project-Based Learning: Creating a Charity Organization/Advocacy Group to Solve a Problem}

\section{Overview}

Each group will create a charity organization or an advocacy group that offers medical services, supplies, or education within a target community.

\section{Rationale}

This project offers student-centered, active, self-guided learning-especially in the types of skills you need in order to be successful in the medical field such as:

- $\quad$ Critical thinking.

- $\quad$ Problem-based learning.

- Collaboration.

- Project/time management.

- Constructive self and peer assessment.

- Interpersonal communication.

- $\quad$ Professional ethics and behavior.

- Information literacy and research skills.

\section{Objectives}

- Explore a subject and identify a problem in a particular community that needs to be addressed such as a dire need of medical services/paucity of medical supplies/education.

- $\quad$ Research the problem and possible solutions.

- $\quad$ Describe the problem and why it is relevant.

- $\quad$ Explain the way(s) your group will remedy the problem.

- $\quad$ Formulate learning objectives.

- $\quad$ Synthesize materials.

- $\quad$ Organize writing and presentation clearly, logically, and concisely.

\section{Activities}

The Research Component

Use the Research Guide to:

- Describe your topic and the intended audience.

- $\quad$ Fill your general knowledge by finding and answering background questions.

- $\quad$ List 2-3 research questions you want to answer about your topic.

- $\quad$ Prepare a list of keywords and synonyms relevant to your topic.

- Clearly and concisely state your focused topic.

- $\quad$ List 4 databases to search. Document the search techniques used. Remember to add any filters.

- Comment on your search results.

- $\quad$ Based on your findings, decide whether you need to rerun the search and use different databases or keywords.

- $\quad$ Pick 3 relevant scholarly resources and write the annotated bibliography in APA style.

- Using the search results, provide a brief outline of your essay.

\section{The Written Component}

Part I-Include the following in a complete write-up of 1,000-1,500 words (use Google docs through Canvas Collaborations):

- $\quad$ Present the problem in a way that will convince the reader/audience how relevant and grave the problem is.

- $\quad$ Find a feasible solution to the problem, which is cost-effective and not too time-consuming.

- $\quad$ Address likely objections to your proposed solution.

- Include a References page (APA style).

Part II-Write a mission statement that reflects your organization's goal(s) and philosophy.

Part III-Devise a budget and how it will be allocated where you must balance quality with cost-effectiveness.

The Presentation Component

In the final weeks of the project, your group will present (20 minutes) your organization, its mission, proposal, and budget. Your group must decide the purpose of your presentation and who your potential audience will be:

- To recruit new doctors.

- To get donors who could help fund your project.

- $\quad$ OR to raise awareness to a government body/call for action.

*Video clips must be limited to only one, no longer than 3 minutes. 


\section{Group Member Roles}

- $\quad$ Project Manager: sets agenda, delegates workload, oversees development of overall plan.

- Facilitator: monitors planning and pacing of phases of the project and when/where meetings take place.

- Scribe: records the notes/tracks progress of each meeting.

\section{Timeline}

Jan. 10 Introduction

Jan. 25 Identify/Describe a problem and propose a tentative solution (200-300 words)

Feb. 8 Mission statement (50-100 words)

Feb.16 Turn in a brief description of the problem-solution along with your Research Guides

sections 1-3

Mar. 7 Proposed budget

Mar. 10 Submit Final Research Guide

Mar. 21 First draft due of write up (1,000-1,500 words including bibliography in APA style)

Apr. 7 Final draft due of write up (1,000-1,500 words including bibliography in APA style)

Apr. 11-14 Group Presentations (20-25 minutes per group member)

Apr. 18-21 Reflections/Evaluations

\section{Evaluation}

You and your group members will be given a survey reflecting on your contribution, each member's role, and the overall experience. There are tools that will allow you to look back and assess what you have learned as a result of this project. Remember that the purpose of the project is self-guided learning on a topic that interests you. Without this part of the project, you would not be able to see the value in not only what you learned, but also how you learned. 